\title{
Inisiasi Pembentukan Buah Mentimun (Cucumis sativus L.) Varietas Mercy F1 secara Partenokarpi akibat Konsentrasi Giberelin dan Dosis Pupuk Kalium \\ (Parthenocarp Fruit Initiation of Cucumber (Cucumis sativus L.) Mercy F1 Variety due to the Concentration of Gibberellins and the Dose of Potassium Fertilizer)
}

\author{
Sarah Afrita Rizky ${ }^{1}$, Mardhiah Hayati ${ }^{1}$, Marai Rahmawati ${ }^{*}$ \\ ${ }^{1}$ Jurusan Agroteknologi, Fakultas Pertanian, Universitas Syiah Kuala \\ *Corresponding author: mrwati@gmail.com
}

\begin{abstract}
Abstrak. Penelitian ini bertujuan untuk mengetahui pengaruh konsentrasi giberelin dan dosis pupuk kalium, serta interaksi keduanya terhadap pertumbuhan dan hasil tanaman mentimun varietas Mercy F1 secara partenokarpi. Penelitian ini dilaksanakan di lahan kebun Gampong Ilie-Ulee Kareng-Banda Aceh, Laboratorium Fisiologi Tumbuhan dan Laboratorium Hortikultura Fakultas Pertanian Universitas Syiah Kuala. Rancangan yang digunakan adalah Rancangan Acak Kelompok pola faktorial 4 x 3 dengan 3 ulangan. Faktor yang diteliti yaitu konsentrasi giberelin (Kontrol, 100, 200 dan 300 ppm) dan dosis pupuk kalium (Kontrol, 100 dan $200 \mathrm{~kg}$ $\mathrm{ha}^{-1}$ ). Hasil penelitian menunjukkan bahwa konsentrasi giberelin berpengaruh sangat nyata terhadap jumlah biji per buah dan bobot buah per tanaman. Hasil mentimun terbaik dijumpai pada konsentrasi giberelin 300 ppm dalam menurunkan jumlah biji per buah. Hasil penelitian juga menunjukkan bahwa dosis pupuk kalium berpengaruh sangat nyata terhadap bobot buah per tanaman dan bobot buah per buah, berpengaruh nyata terhadap jumlah buah per tanaman dan panjang buah per buah. Hasil mentimun terbaik dijumpai pada dosis 200 $\mathrm{kg} \mathrm{ha}^{-1}$ pupuk kalium dalam meningkatkan bobot buah per buah dan panjang buah per buah. Interaksi antara konsentrasi giberelin dan dosis pupuk kalium berpengaruh nyata terhadap jumlah buah per tanaman dan jumlah biji per buah. Hasil mentimun terbaik dijumpai pada kombinasi konsentrasi giberelin 300 ppm dengan dosis pupuk kalium $100 \mathrm{~kg} \mathrm{ha}^{-1}$.
\end{abstract}

Kata kunci : Giberelin, inisiasi, mentimun, mercy F1, partenokarpi, pupuk kalium.

Abstract. This study aims to determine the effect of gibberellins concentration and potassium fertilizer dosage, as well as their interaction on the growth and yield of Mercy F1 cucumber plant by parthenocarpy. This research was carried out in the gardens of Gampong Ilie-Ulee Kareng-Banda Aceh, Plant Physiology Laboratory and Horticultural Laboratory, Faculty of Agriculture, Syiah Kuala University. The design used was a Randomized Factorial Block Design 3 x 4 with 3 replications. The factors observed were the concentration of gibberellins (Control, 100, 200 and $300 \mathrm{ppm}$ ) and the dose of potassium fertilizer (Control, 100 and $200 \mathrm{~kg} \mathrm{ha}^{-1}$ ). The results showed that the concentration of gibberellins had a very significant effect on the number of seeds by fruit and fruit weight by plant. The best cucumber yields were found at a concentration of $300 \mathrm{ppm}$ gibberellins in reducing the number of seeds by fruit. The results also showed that the dose of potassium fertilizer had a very significant effect on fruit weight by plant and fruit weight by fruit, significantly affected the number of fruits by plant and fruit length by fruit. The best cucumber yield was found at a dose of $200 \mathrm{~kg} \mathrm{ha}^{-1}$ of potassium fertilizer in increasing fruit weight by fruit and fruit length per fruit. The interaction between the concentration of gibberellins and the dose of potassium fertilizer significantly affected the number of fruits by plant and the number of seeds by fruit. The best cucumber yields were found in a combination of $300 \mathrm{ppm}$ gibberellin concentration with a dose of $100 \mathrm{~kg}$ ha-1 potassium fertilizer.

Keywords: Cucumber, gibberellin, initiation, potassium fertilizer, mercy F1, parthenocarpi.

\section{PENDAHULUAN}

Mentimun (Cucumis sativus L.) merupakan salah satu komoditas hortikultura jenis sayuran yang populer dan disukai oleh konsumen Indonesia. Mentimun termasuk dalam family Curcubitaceae yang dapat dikonsumsi segar sebagai lalapan, diolah menjadi asinan, dimanfaatkan sebagai bahan dasar kosmetik untuk kecantikan, dan komposisi dasar obatobatan. Mentimun memiliki kandungan gizi yang baik seperti, protein, karbohidrat, fosfor, zat besi, vitamin A, vitamin B1, vitamin B2, dan mineral (Hermawan, 2015). 
Jepang merupakan negara pengekspor mentimun yang memiliki standar khusus untuk jenis mentimun yang akan diekspor. Standar utamanya yaitu buah mentimun tanpa biji, bebas rasa pahit, ukuran buah yang besar dan bentuk buah tidak rusak (Muchtadi dan Sugiyono, 2014). Mentimun varietas Mercy memiliki standarisasi yang baik tetapi mentimun ini masih memiliki biji. Sebagian besar petani juga banyak menanam jenis mentimun varietas ini dikarenakan keistimewaannya memiliki ukuran buah yang cukup besar, bebas rasa pahit, dan tekstur buah yang sehingga banyak digunakan sebagai lalapan. Selain itu umur panen untuk varietas ini relatif cepat yaitu sekitar 34-36 hari (Padmiarso, 2019).

Produksi mentimun di Indonesia setiap tahunnya mengalami penurunan tercatat sejak tahun 2013, secara nasional produktifitas tanaman mentimun pada tahun 2018 yaitu 433,9 ton dan hasil produksi tanaman mentimun pada tahun 2018 yakni 10,89 ton ha ${ }^{-1}$, ini mengalami peningkatan dibandingkan dengan produksi mentimun pada tahun sebelumnya (BPS, 2019). Selain dari data yang tertera, mengenai permintaan dari pasar Jepang terhadap mentimun umumnya 50.000 ton per tahun, khususnya berbentuk "Pickling Cucumber" atau lebih dikenal dengan asinan mentimun. Kualitas dan kuantitas mentimun lokal Indonesia harus ditingkatkan karena Indonesia memegang peluang besar untuk menjadi penyuplai ekspor ke negara Jepang dengan memenuhi syarat standar yang dinginkan negara Jepang. Produksi mentimun Indonesia masih sangat rendah dibawah 2.000 ton per tahun padahal telah mengeksploitasi peluang ke pasar Jepang (Rukmana, 2015).

Upaya dalam meningkatkan buah mentimun tanpa biji adalah dengan inisiasi partenokarpi. Partenokarpi merupakan proses fertilisasi yang terjadi pada suatu tanaman tanpa adanya polinasi, sehingga buah yang dihasilkan tanpa biji (Rezaldi et al., 2019). Berdasarkan hal tersebut, dapat dilihat bahwa tujuan partenokarpi adalah untuk menghasilkan buah tanpa biji, dan selanjutnya oleh karena buah yang dihasilkan adalah tanpa biji, maka hal ini menjadi bermanfaat untuk meningkatkan produktifitas dan kualitas yang lebih baik (Kawamura et al., 2018). Partenokarpi dibagi menjadi dua teknik, yaitu partenokarpi alami dan partenokarpi buatan (Rezaldi et al., 2019). Pada partenokarpi buatan dilakukan dengan memanfaatkan hormon pertumbuhan tanaman (Liu et al., 2018).

Zat pengatur tumbuh yang sudah dimanfaatkan untuk pembentukan buah partenokarpi adalah giberelin dengan penyemprotan maupun pencelupan pada kuncup bunga (Adnyesuari et al., 2015). Pada mentimun untuk pembentukan buah mentimun yang bersifat partenokarpi biasanya terinduksi dengan terakumulasinya jumlah hormon auksin yang terdapat dalam ovarium (Rezaldi et al., 2019). Partenokarpi dengan pemberian zat pengatur tumbuh giberelin memberikan efek pembentukan biji yang tidak terbentuk karena pertumbuhan tabung sari sebelum pembuahan mengalami gangguan. Pembuahan dapat terjadi apabila tepung sari berpolinasi dengan putik, sehingga pembentukan biji dan embrio diiringi dengan pembentukan buah (Lolaei et al., 2013). Tingkat keberhasilan pembuahan ini mencapai hampir $100 \%$ berdasarkan penelitian Wulandari et al. $\left(2014^{\mathrm{b}}\right)$ dengan perlakuan giberelin yang terbukti sangat berpengaruh terhadap pembentukan buah tanpa biji pada mentimun secara partenokarpi pada konsentrasi giberelin 200 ppm yang memiliki hasil terbaik, serta hasil buah yang signifikan pada jumlah biji buah mentimun.

Meningkatkan kualitas buah perlu adanya kecukupan pupuk, terutama pupuk kalium. Kalium berperan dalam memperkokoh bunga, daun, dan buah agar tidak lasuh gugur, merupakan sumber resistensi bagi tanaman dalam menghadapi penyakit maupun kekeringan, serta membantu transportasi gula dari daun ke buah (Suprihatin, 2011). Pupuk kalium yang banyak digunakan di Indonesia saat ini adalah Kalium (kalium klorida) dengan kadar 60\% $\mathrm{K}_{2} \mathrm{O}$. Adapun pada tanaman mentimun, pemberian pupuk kalium ini mampu meningkatkan perkembangan buah, jumlah biji, dan pesentase biji bernas (Hudah et al., 2019). Menurut 
hasil penelitian Makuta (2013) tentang pemberian pupuk kalium terhadap tanaman mentimun, bahwa pupuk kalium dosis $200 \mathrm{~kg} \mathrm{ha}^{-1}$ mampu meningkatkan pertumbuhan dan produksi mentimun. Hal ini disebabkan oleh dosis pupuk kalium yang tepat sehingga meningkatkan pertumbuhan tanaman serta pupuk kalium sangat diperlukan untuk perkembangan tanaman.

Berdasarkan hal-hal tersebut maka perlu adanya penelitian lebih lanjut pada tanaman mentimun khususnya varietas mercy untuk menginisiasi pembentukan buah mentimun secara partenokarpi dengan memberikan perlakuan konsentrasi giberelin dan dosis pupuk Kalium yang berbeda-beda.

\section{METODE PENELITIAN}

Penelitian ini dilaksanakan di lahan kebun Gampong Ilie-Ulee Kareng-Banda Aceh, Laboratorium Fisiologi Tumbuhan dan Laboratorium Hortikultura Fakultas Pertanian Universitas Syiah Kuala.

\section{MATERI DAN METODE}

\section{Alat dan Bahan Penelitian}

Alat-alat yang digunakan adalah cangkul, handsprayer, gunting, jangka sorong, gembor, meteran, oven, timbangan, kalkulator, wadah, kayu, tali nilon, kamera, buku catatan, label dan alat tulis. Bahan-bahan yang digunakan dalam penelitian ini adalah benih mentimun varietas Mercy F1 satu saset isi 400 butir, zpt giberelin satu tablet $10 \mathrm{~g}$, pupuk kalium $250 \mathrm{~g}$, pupuk NPK $150 \mathrm{~g}$, pupuk SP-36 $50 \mathrm{~g}$, pupuk kompos $15 \mathrm{~kg}$, polybag ukuran 40 x $40 \mathrm{~cm}$ sebanyak 108 buah.

\section{Rancangan Percobaan}

Penelitian ini menggunakan Rancangan Acak Kelompok (RAK) pola faktorial 4 x 3 dengan 3 ulangan, sehingga terdapat 12 kombinasi perlakuan dan 36 unit percobaan. Ada dua faktor yang diteliti yaitu faktor pertama konsentrasi giberelin $(G)$ terdiri dari 4 taraf yaitu $G_{0}$ $=$ Kontrol, $\mathrm{G}_{1}=100 \mathrm{ppm}, \mathrm{G}_{2}=200 \mathrm{ppm}$, dan $\mathrm{G}_{3}: 300 \mathrm{ppm}$; serta faktor kedua dosis pupuk kalium $(\mathrm{K})$ terdiri dari 3 taraf yaitu $\mathrm{K}_{0}=$ Kontrol, $\mathrm{K}_{1}=100 \mathrm{~kg} \mathrm{ha}^{-1}(0,75 \mathrm{~g}$ per polybag), dan $\mathrm{K}_{2}=200 \mathrm{~kg} \mathrm{ha}^{-1}(1,5 \mathrm{~g}$ per polybag). Setelah data diperoleh, selanjutnya data dianalisis secara statistik dengan ANOVA (analysis of variance). Data dianalisis dengan menggunakan uji F, untuk mengetahui pengaruh perlakuan. Apabila perlakuan berpengaruh nyata, maka dilakukan analisis lanjut menggunakan uji BNT pada taraf 5\%.

\section{Pelaksanaan Penelitian}

Persiapan lahan dimulai dengan membersihkan areal penanaman lahan dari gulma dan bebatuan. Persiapan media tanam dilakukan dengan mencampurkan tanah dan pupuk organik kompos berdasarkan volume yaitu, tanah:kompos (2:1), setelah tercampur media tanam dimasukkan ke dalam polybag. Polybag disusun dengan jarak antar polybag $40 \mathrm{~cm}$ dan antar blok $60 \mathrm{~cm}$. Selanjutnya diberikan pupuk NPK sebanyak 1,13 g dan pupuk SP36 sebanyak $0,38 \mathrm{~g}$ per polybag. Benih mentimun yang digunakan jenis varietas Mercy F1. Benih direndam dalam air selama 5 menit dan diperam selama 12 jam. Kemudian benih ditanam dengan kedalam $3 \mathrm{~cm}$, masing-masing dua benih per lubang tanam. Pemberian pupuk kalium sesuai dengan dosis perlakuan yaitu $\mathrm{K}_{0}$ : Kontrol, $\mathrm{K}_{2}: 100 \mathrm{~kg} \mathrm{ha}^{-1}\left(0,75 \mathrm{~g}\right.$ per polybag), dan $\mathrm{K}_{3}$ : $200 \mathrm{~kg} \mathrm{ha}^{-1}$ (1,5 g per polybag) diberikan pada awal penanaman. Pengaplikasian giberelin sesuai konsentrasi perlakuan yaitu $\mathrm{G}_{1}: 100 \mathrm{ppm}$ (100 $\mathrm{mg} \mathrm{L}^{-1}$ giberelin), $\mathrm{G}_{2}: 200 \mathrm{ppm}$ (200 mg $\mathrm{L}^{-1}$ giberelin), $\mathrm{G}_{3}: 300 \mathrm{ppm}$ (300 mg L $\mathrm{m}^{-1}$ giberelin) dengan cara menyemprot kepala putik 
betina dengan volume $20 \mathrm{ml}$ sebanyak dua kali ulangan dengan selang waktu 24 jam pada pagi hari pukul 06.00 - 07.00 WIB karena aplikasi giberelin pada tanaman tidak boleh terpapar sinar matahari secara langsung. Giberelin yang telah disemprot ditandai dengan label, pengaplikasian dilakukan dua kali yaitu pada umur 25 dan 27 HST. Pemeliharaan tanaman mentimun terdiri dari penyiraman, penyulaman, pengajiran, penyiangan dan pengendalian organisme pengganggu tanaman. Pemanenan dilakukan 3 kali yaitu pada saat buah mentimun berumur 40, 44, dan 48 HST dengan kriteria buah mentimun yang sudah siap panen.

\section{Parameter Pengamatan}

Adapun parameter yang diamati dalam penelitian ini adalah tinggi tanaman pada saat tanaman mentimun berumur 10, 20, dan 30 HST, bobot berangkasan basah per tanaman yang diamati pada saat tanaman mentimun berumur 48 HST, bobot berangkasan kering per tanaman mentimun yang telah dikeringkan dengan oven selama 3 x 24 jam pada suhu $60^{\circ} \mathrm{C}$ sampai diperoleh berat konstan, jumlah buah per tanaman, bobot buah per tanaman, bobot buah per buah, jumlah biji per buah, panjang buah per buah, dan diameter buah per buah.

\section{HASIL DAN PEMBAHASAN}

\section{Pengaruh Konsentrasi Giberelin terhadap Pertumbuhan dan Hasil Tanaman Mentimun}

Hasil uji F (Tabel Lampiran 1) menunjukkan bahwa konsentrasi giberelin berpengaruh sangat nyata terhadap bobot buah per tanaman, jumlah biji per buah, dan berpengaruh tidak nyata terhadap peubah lainnya. Rata-rata pertumbuhan dan hasil tanaman mentimun akibat pemberian konsentrasi giberelin dapat dilihat pada Tabel 1.

Tabel 1. Rata-rata pertumbuhan dan hasil tanaman mentimun akibat konsentrasi giberelin

\begin{tabular}{|c|c|c|c|c|c|c|}
\hline \multirow{2}{*}{\multicolumn{2}{|c|}{ Parameter yang diamati }} & \multicolumn{4}{|c|}{ Konsentrasi Giberelin (ppm) } & \multirow{2}{*}{$\begin{array}{c}\text { BNT } \\
0,05\end{array}$} \\
\hline & & Kontrol & 100 & 200 & 300 & \\
\hline \multirow{3}{*}{ Tinggi Tanaman $(\mathrm{cm})$} & $10 \mathrm{HST}$ & 10,75 & 12,59 & 11,36 & 11,80 & \\
\hline & 20 HST & 61,45 & 62,34 & 63,22 & 59,04 & \\
\hline & 30 HST & 165,43 & 177,29 & 168,95 & 153,62 & \\
\hline \multicolumn{2}{|c|}{ Bobot Berangkasan Basah (g) } & 204,05 & 222,97 & 214,08 & 214,07 & \\
\hline \multicolumn{2}{|c|}{ Bobot Berangkasan Kering (g) } & 33,68 & 37,79 & 36,30 & 36,30 & \\
\hline \multicolumn{2}{|c|}{ Jumlah Buah per Tanaman } & 1,93 & 2,04 & 1,56 & 1,67 & \\
\hline \multicolumn{2}{|c|}{ Bobot Buah per Tanaman (g) } & $496,63 \mathrm{~b}$ & $481,85 \mathrm{~b}$ & $323,33 \mathrm{a}$ & $357,41 \mathrm{a}$ & 103,45 \\
\hline \multicolumn{2}{|c|}{ Bobot Buah per Buah (g) } & 213,33 & 220,37 & 179,63 & 191,85 & \\
\hline \multicolumn{2}{|l|}{ Jumlah Biji per Buah } & $477,89 \mathrm{~d}$ & $395,93 \mathrm{c}$ & $341,96 \mathrm{~b}$ & $265,74 \mathrm{a}$ & 50,41 \\
\hline \multicolumn{2}{|c|}{ Panjang Buah per Buah (cm) } & 15,39 & 17,11 & 16,47 & 16,82 & \\
\hline \multicolumn{2}{|c|}{ Diameter Buah per Buah (mm) } & 33,68 & 37,79 & 36,30 & 36,29 & \\
\hline
\end{tabular}

Keterangan: Angka yang diikuti huruf yang sama pada baris yang sama berbeda tidak nyata pada taraf 5\% $\left(\mathrm{BNT}_{0,05}\right)$

Hasil penelitian menunjukkan bahwa bobot buah mentimun per tanaman lebih besar pada perlakuan yang tidak diberi konsentrasi giberelin dan berbeda tidak nyata dengan konsentrasi giberelin 100 ppm, namun berbeda nyata dengan konsentrasi giberelin 200 dan 300 ppm. Hal ini sesuai dengan Suhartono et al. (2020), bahwa bobot buah mentimun per 
buah cenderung lebih tinggi pada perlakuan yang tidak diberikan konsentrasi giberelin dalam meningkatkan bobot buah mentimun, dikarenakan buah hasil proses fertilisasi mempunyai jumlah biji lebih banyak dari proses pembentukan buah secara partenokarpi, sehingga semakin besar persediaan hormon dalam pengembangan maupun pembelahan sel dan berkurangnya biji dalam proses partenokarpi menimbulkan bobot buah yang cenderung lebih kecil dibandingkan proses fertilisasi. Jumlah biji mentimun per buah terendah pada konsentrasi 300 ppm giberelin yang berbeda nyata dengan perlakuan lainnya Hal ini sesuai dengan Suhartono et al. (2020), bahwa aplikasi konsentrasi giberelin 300 ppm menunjukkan pengaruh nyata terhadap jumlah biji dimana semakin kecil jumlah biji yang berada dalam buah mentimun disebabkan oleh banyaknya konsentrasi giberelin yang diberikan. Konsentrasi giberelin 300 ppm dapat menaikkan kadar auksin yang akan menghambat buluh serbuk sari sampai ke bagian mikropil pada ovarium sehingga perkembangan buluh serbuk sari terhenti dan zigot tidak dapat terbentuk karena serbuk sari tidak dapat bertemu dengan sel telur. Zigot yang tidak terbentuk menimbulkan perkembangan bakal biji yang tidak terbentuk (Lolaei et al., 2013).

\section{Pengaruh Dosis Pupuk Kalium terhadap Pertumbuhan dan Hasil Tanaman Mentimun}

Hasil uji F (Tabel Lampiran 1) menunjukkan bahwa dosis pupuk kalium berpengaruh sangat nyata terhadap bobot buah per tanaman dan bobot buah per buah, berpengaruh nyata terhadap jumlah buah per tanaman dan panjang buah per buah, dan berpengaruh tidak nyata terhadap peubah lainnya. Rata-rata pertumbuhan dan hasil tanaman mentimun akibat pemberian konsentrasi giberelin dan dosis pupuk kalium dapat dilihat pada Tabel 2.

Tabel 2. Rata-rata pertumbuhan dan hasil tanaman mentimun akibat dosis pupuk Kalium

\begin{tabular}{|c|c|c|c|c|c|}
\hline \multirow{2}{*}{\multicolumn{2}{|c|}{ Parameter yang diamati }} & \multicolumn{3}{|c|}{ Dosis Pupuk Kalium $\left(\mathrm{kg} \mathrm{ha}^{-1}\right)$} & \multirow{2}{*}{$\mathrm{BNT}_{0,0}$} \\
\hline & & Kontrol & 100 & 200 & \\
\hline \multirow[t]{3}{*}{ Tinggi Tanaman $(\mathrm{cm})$} & $10 \mathrm{HST}$ & 10,83 & 12,59 & 11,36 & \\
\hline & $20 \mathrm{HST}$ & 61,45 & 62,34 & 63,22 & \\
\hline & $30 \mathrm{HST}$ & 165,43 & 177,29 & 168,95 & \\
\hline \multicolumn{2}{|c|}{ Bobot Berangkasan Basah (g) } & 199,97 & 220,17 & 221,24 & \\
\hline \multicolumn{2}{|c|}{ Bobot Berangkasan Kering (g) } & 33,30 & 36,84 & 37,90 & \\
\hline \multicolumn{2}{|c|}{ Jumlah Buah per Tanaman } & 1,50 & 2,00 & 1,89 & 0,35 \\
\hline \multicolumn{2}{|c|}{ Bobot Buah per Tanaman (g) } & $307,50 \mathrm{a}$ & $476,94 b$ & $439,72 \mathrm{~b}$ & 89,59 \\
\hline \multicolumn{2}{|c|}{ Bobot Buah per Buah $(\mathrm{g})$} & $170,28 \mathrm{a}$ & $216,67 \mathrm{~b}$ & $216,94 \mathrm{~b}$ & 32,46 \\
\hline \multicolumn{2}{|l|}{ Jumlah Biji per Buah } & 340,80 & 391,61 & 378,61 & \\
\hline \multicolumn{2}{|c|}{ Panjang Buah per Buah $(\mathrm{cm})$} & 14,51 a & $16,93 \mathrm{~b}$ & 17,90 & 2,41 \\
\hline \multicolumn{2}{|c|}{ Diameter Buah per Buah (mm) } & 33,30 & 36,84 & 37,90 & \\
\hline
\end{tabular}

Keterangan: Angka yang diikuti huruf yang sama pada baris yang sama berbeda tidak nyata pada taraf 5\% $\left(\mathrm{BNT}_{0,05}\right)$

Hasil penelitian menunjukkan bahwa jumlah buah mentimun per tanaman dan bobot buah per tanaman yang lebih tinggi dijumpai pada dosis $100 \mathrm{~kg} \mathrm{ha}^{-1}$ pupuk kalium yang berbeda tidak nyata dengan dosis $200 \mathrm{~kg} \mathrm{ha}^{-1}$ pupuk kalium, namun berpengaruh nyata terhadap perlakuan yang tidak diberi dosis pupuk kalium. Bobot buah per buah dan panjang buah per buah yang lebih tinggi pada dosis $200 \mathrm{~kg} \mathrm{ha}^{-1}$ pupuk kalium yang berbeda tidak nyata dengan dosis $100 \mathrm{~kg} \mathrm{ha}^{-1}$ pupuk kalium, namun berbeda nyata terhadap perlakuan yang tidak diberi dosis pupuk kalium. Hal ini sejalan dengan Makuta (2013), yang menyatakan bahwa dosis pupuk kalium $200 \mathrm{~kg} \mathrm{ha}^{-1}$ berpengaruh nyata terhadap panjang buah, jumlah 
buah, dan bobot buah, namun sebaliknya dengan pernyataan Hudah et al. (2019), tentang pemberian dosis pupuk kalium $300 \mathrm{~kg} \mathrm{ha}^{-1}$ pada tanaman mentimun mampu meningkatkan produksi dan kualitas buah mentimun. Letak tumbuh buah mentimun mempengaruhi panjang buah dimana buah yang tumbuh langsung pada ketiak daun dan buahnya tunggal biasanya relatif lebih panjang dan mulus (Daulay, 2020). Jumlah buah pada tanaman mentimun berkaitan dengan proses penyerbukan pada bunga betina yang tidak mengalami kerontokkan serta meningkatnya jumlah buah juga diakibatkan oleh pemberian dosis pupuk yang tepat. Pada saat pertumbuhan, ketersediaan unsur hara yang cukup menyebabkan aktifnya metabolisme tanaman sehingga proses perkembangan sel akan menggerakkan peningkatan bobot buah mentimun serta panjang dari buahnya (Yasmin et al., 2014).

\section{Pengaruh Interaksi antara Konsentrasi Giberelin dan Dosis Pupuk Kalium terhadap Hasil Tanaman Mentimun}

Hasil uji F (Tabel Lampiran 1) menunjukkan bahwa interaksi antara konsentrasi giberelin dan dosis pupuk kalium berpengaruh nyata terhadap jumlah buah per tanaman dan jumlah biji per buah. Rata-rata jumlah buah per tanaman dan jumlah biji per buah tanaman mentimun akibat interaksi antara konsentrasi giberelin dan dosis pupuk kalium dapat dilihat pada Tabel 3.

Tabel 3. Rata-rata jumlah buah per tanaman dan jumlah biji per buah akibat interaksi antara konsentrasi giberelin dan dosis pupuk kalium

\begin{tabular}{cccccc}
\hline \multirow{2}{*}{$\begin{array}{c}\text { Parameter yang } \\
\text { diamati }\end{array}$} & $\begin{array}{c}\text { Konsentrasi } \\
\text { Giberelin }(\mathrm{ppm})\end{array}$ & \multicolumn{3}{c}{ Pupuk Kalium $\left(\mathrm{kg} \mathrm{ha}^{-1}\right)$} & BNT \\
\cline { 3 - 5 } & Kontrol & $1,33 \mathrm{Aa}$ & $2,89 \mathrm{Bb}$ & $1,56 \mathrm{Aa}$ & \\
\hline \multirow{2}{*}{ Jumlah Buah } & 100 & $1,67 \mathrm{Aa}$ & $2,00 \mathrm{Aba}$ & $2,44 \mathrm{Bbc}$ & 0,70 \\
per Tanaman & 200 & $1,33 \mathrm{Aa}$ & $1,56 \mathrm{Aa}$ & $1,78 \mathrm{Aab}$ & \\
& 300 & $1,67 \mathrm{Aa}$ & $1,56 \mathrm{Aa}$ & $2,67 \mathrm{Bc}$ & \\
\hline \multirow{2}{*}{ Jumlah Biji } & Kontrol & $365,89 \mathrm{Aa}$ & $573,89 \mathrm{Bc}$ & $493,89 \mathrm{Bc}$ & \\
per Buah & 100 & $330,44 \mathrm{Aa}$ & $428,67 \mathrm{Ab}$ & $428,67 \mathrm{Ab}$ & 100,83 \\
& 200 & $360,78 \mathrm{Aa}$ & $332,11 \mathrm{Aab}$ & $333,00 \mathrm{Aab}$ & \\
\hline
\end{tabular}

Keterangan: Angka yang diikuti oleh huruf yang sama (huruf kapital dilihat secara horizontal dan huruf kecil dilihat secara vertikal) berbeda tidak nyata pada taraf $5 \%\left(\mathrm{Uji} \mathrm{BNT}_{0.05}\right)$

Hasil penelitian menunjukkan bahwa terdapat interaksi yang nyata antara konsentrasi giberelin dan dosis pupuk kalium terhadap jumlah buah per tanaman dan jumlah biji per buah, namun berpengaruh tidak nyata terhadap peubah lainnya. Hasil terbaik dijumpai pada kombinasi konsentrasi giberelin perlakuan Kontrol dengan dosis $100 \mathrm{~kg} \mathrm{ha}^{-1}$ pupuk kalium dalam meningkatkan jumlah buah mentimun per tanaman dan kombinasi konsentrasi 300 ppm giberelin dengan dosis $100 \mathrm{~kg} \mathrm{ha}^{-1}$ pupuk kalium dalam menurunkan jumlah biji mentimun per buah. Hal ini menandakan bahwa jika pemberian konsentrasi giberelin perlakuan Kontrol digunakan bersamaan dengan pemberian dosis $100 \mathrm{~kg} \mathrm{ha}^{-1}$ pupuk kalium maka akan menghasilkan jumlah buah per tanaman tertinggi dan konsentrasi 300 ppm giberelin dengan dosis $100 \mathrm{~kg} \mathrm{ha}^{-1}$ pupuk kalium akan menghasilkan jumlah biji terendah. Konsentrasi giberelin 300 ppm tidak menyebabkan hasil buah mentimun tanpa biji tetapi hanya memberikan efek jumlah biji yang terbentuk berkurang. Hal ini dikarenakan terjadinya gangguan pada saat proses pembentukan bakal biji sehingga bentuk biji mentimun lebih kecil 
dan lunak. Pemberian zat pengatur tumbuh giberelin dengan konsentrasi yang tinggi dapat menghasilkan jumlah biji mentimun semakin sedikit (Yasmin et al., 2014). Pengaplikasian giberelin dengan konsentrasi 300 ppm memberikan hasil pertumbuhan buah menjadi lebih kecil. Hal ini sebaliknya dengan pernyataan Adnyesuari et al. (2015) pemberian giberelin dengan konsentrasi 300 ppm memberikan hasil terbaik terhadap bobot buah tanaman mentimun.

\section{KESIMPULAN DAN SARAN}

Hasil penelitian menunjukkan bahwa konsentrasi giberelin hasil mentimun terbaik dijumpai pada konsentrasi giberelin 300 ppm. Dosis pupuk Kalium menunjuukkan bahwa hasil mentimun terbaik dijumpai pada dosis $100 \mathrm{~kg} \mathrm{ha}^{-1}$ pupuk Kalium dan dosis $200 \mathrm{~kg} \mathrm{ha}^{-1}$ pupuk Kalium. Konsentrasi giberelin dan dosis pupuk Kalium terdapat interaksi pada kombinasi konsentrasi giberelin perlakuan kontrol dengan dosis $100 \mathrm{~kg} \mathrm{ha}^{-1}$ pupuk Kalium.

\section{DAFTAR PUSTAKA}

Adnyesuari, A. A., R. H. Murti, dan S. Mitrowihardho. 2015. Induksi partenokarpi pada tiga genotipe tomat dengan . Jurusan Budidaya Pertanian. Universitas Gajah Mada. Yogyakarta. Jurnal Ilmu Pertanian. 18(1): 56-62.

BPS. 2019. Statistik indonesia statistical yearbook of indonesia 2019. Badan Pusat Statistik. Jakarta.

Daulay, K. B. 2020. Pupuk KCl dan urin kambing berpengaruh terhadap pertumbuhan dan hasil tanaman mentimun jepang (Cucumis sativus var. japonese) Skripsi. Jurusan Agroteknologi. Fakultas Pertanian. Universitas Muhammadiyah Sumatera Utara.

Hermawan, A. 2015. Kajian sifat sisik buah mentimun (Cucumis sativus L.) menggunakan pengolahan citra (Image Processing). Skripsi. Jurusan Teknik Pertanian. Fakultas Teknologi Pertanian. Universitas Jember. Jember.

Hudah, M., S. Hartatik, S. Soeparjono, dan Suharto. 2019. Pengaruh pemangkasan pucuk dan pupuk kalium terhadap produksi dan kualitas benih mentimun (Cucumis sativus L.). Universitas Jember. Jurnal Bioindustri. 1(2): 176-185.

Kawamura, S., K. Ida, M. Osawa, and T. Ikeda. 2018. No effect of seed presence or absence on sugar content and water status of seeded and seedless watermelon fruits. HortScience. 53(3): 304-312.

Liu, S., Y. Zhang, Q. Feng, L. Qin, C. Pan, A. T. Lamin-Samu, and G. Lu. 2018. Tomato auxin response factor 5 regulates fruit set and development via the mediation of auxin and gibberellin signaling. Scientific reports. 8(1): 2971.

Lolaei, A., N. Teymouri, R. Bemana, A. K, Pour, dan S. Aminian. 2013. Effect of gibberellin on vegetative and sexual growth and fruit quality of strawberry (Fragaria x Ananassa duch. Cv. Selva and Qeen elisa). Agriculture and Crop Sciences. 5(14): 1508-1513.

Makuta, D. T. 2013. Pengaruh pemberian pupuk Kalium terhadap pertumbuhan dan produksi tanaman mentimun (Cucumis sativus L.). Skripsi. Program Studi Agroteknologi.

Muchtadi, T. R, dan Sugiyono. 2014. Prinsip Proses Dan Teknologi Pangan. Alvabeta. Bandung.

Padmiarso, M. W. 2019. Budidaya Mentimun yang Lebih Menguntungkan. Pustaka Agro. Jakarta. 
Rezaldi, F., M. A. H., Qonit, S. Mubarok, A. Nuraini, dan Kusumiyati. 2019. Pemanfaatan fenomena pembentukan buah partenokarpi dalam perspektif pertanian di Indonesia. Jurnal Kultivasi. 18(2): 859-868.

Rukmana, R. 2015. Budidaya Mentimun. Kanisius. Yogyakarta.

Suhartono. Arsyadmunir, A. Firdaus, I. Z. 2020. Induksi partenokarpi dengan $\mathrm{GA}_{3}$ pada mentimun (Cucumis sativus L.) lokal madura. Jurnal Agrovigor. 13(1): 82-88.

Suprihatin. 2011. Proses pembuatan pupuk cair dari batang pohon pisang. Fakultas Teknologi Industri UPN. Jawa Timur. Jurnal Teknik Kimia. 5(2):429-433.

Tani ternak organik. 2015. SOP budidaya mentimun secara organik. https://taniternakorganik.blogspot.com/2015/02/sop-budidaya-mentimun-secaraorganik.html?m=1. Diakses tanggal : 10 April 2020.

Wulandari, D. W., Y. S. Rahayu, dan E. Ratnasari. 2014 ${ }^{\mathrm{a}}$. Pengaruh pemberian hormon giberelin terhadap pembentukan buah secara partenokarpi pada tanaman mentimun varietas mercy. Jurnal Lentera Bio. 3(1): 27-32.

Wulandari, E., B. Guritno, dan N. Aini. $2014^{\mathrm{b}}$. Pengaruh kombinasi jumlah tanaman per polybag dan komposisi media tanam terhadap pertumbuhan dan hasil tanaman mentimun (Cucumis sativus L.) varietas venus. Jurnal Produksi Tanaman. 2(6): 465473.

Yasmin, S., T. Wardiyanti. Dan Koesriharti. 2014. Pengaruh perbedaan waktu dan konsentrasi giberelin terhadap pertumbuhan dan hasil tanaman cabai besar (Capsicum annum L.). Jurnal Produksi Tanaman. 2(5): 395-403.

\section{LAMPIRAN}

Lampiran 1. Rekapitulasi hasil analisis ragam inisiasi pembentukan buah mentimun varietas mercy F1 secara partenokarpi akibat konsentrasi giberelin dan dosis pupuk kalium

\begin{tabular}{|c|c|c|c|c|}
\hline \multirow{2}{*}{ Parameter } & \multicolumn{3}{|c|}{ Perlakuan } & \multirow{2}{*}{$\mathrm{KK}(\%)$} \\
\hline & $\mathrm{G}$ & $\mathrm{K}$ & $\mathrm{G} \times \mathrm{K}$ & \\
\hline Tinggi Tanaman 10 HST $(\mathrm{cm})$ & $0,93^{\mathrm{tn}}$ & $0,97^{\text {tn }}$ & $0,86^{\text {tn }}$ & 20.72 \\
\hline Tinggi Tanaman 20 HST $(\mathrm{cm})$ & $0,16^{\mathrm{tn}}$ & $1,36^{\mathrm{tn}}$ & $1,72^{\text {tn }}$ & 21.84 \\
\hline Tinggi Tanaman 30 HST $(\mathrm{cm})$ & $1,04^{\mathrm{tn}}$ & $0,66^{\text {tn }}$ & $1,28^{\mathrm{tn}}$ & 17.40 \\
\hline Bobot Brangkasan Basah (g) & $0,39^{\mathrm{tn}}$ & $1,26^{\mathrm{tn}}$ & $2,08^{\text {tn }}$ & 17.29 \\
\hline Bobot Brangkasan Kering (g) & $0,62^{\mathrm{tn}}$ & $1,66^{\text {tn }}$ & $2,17^{\text {tn }}$ & 17.99 \\
\hline Jumlah Buah per Tanaman & $2,59^{\mathrm{tn}}$ & $4,78^{*}$ & $3,73^{*}$ & 23.16 \\
\hline Bobot Buah per Tanaman (g) & $5,09^{* *}$ & $8,50^{* *}$ & $2,26^{\mathrm{tn}}$ & 25.93 \\
\hline Bobot Buah per Buah (g) & $2,18^{\mathrm{tn}}$ & $5,89^{* *}$ & $1,73^{\text {tn }}$ & 19.05 \\
\hline Jumlah Biji per Buah & $20,28^{* *}$ & $2,37^{\text {tn }}$ & $3,69^{*}$ & 16.07 \\
\hline Panjang Buah per Buah $(\mathrm{cm})$ & $0,63^{\mathrm{tn}}$ & $4,54^{*}$ & $2,08^{\mathrm{tn}}$ & 17.28 \\
\hline Diameter Buah per Buah (mm) & $0,62^{\mathrm{tn}}$ & $1,66^{\text {tn }}$ & $2,17^{\text {tn }}$ & 17.99 \\
\hline
\end{tabular}

Keterangan: **: sangat nyata pada taraf $0,01($ uji $\mathrm{F}) ; *$ : nyata pada taraf 0,05 ; tn: tidak nyata; G: konsentrasi giberelin; K: dosis pupuk kalium; GxK: interaksi antara konsentrasi giberelin dan dosis pupuk kalium; KK: koefisiensi keragaman (\%) 